\title{
Studi Kelayakan Pemilihan Supplier Perlengkapan Dan ATK Menggunakan Metode SAW (Simple Additive Weighting)
}

\author{
Juniar Hutagalung \\ Peneliti dan Dosen Sistem Informasi, STMIK Triguna Dharma \\ Jl. Jenderal Besar A.H. Nasution No.73, Medan Johor, Kota Medan \\ juniarhutagalung77@gmail.com
}

\begin{abstract}
Office Supplies and Stationery (ATK) are equipment that is often used in offices, companies and organizations, include cabinet filling, perforators, calculators, paper clips, staplers, numerators, guides, flashdisks, paper punches, pens and paper, paper shredder, computers, printers, facsimile machines, photocopiers, archive folders and cash registers, office furniture. Supplier is part of the supplier chain that influences the development of a company. Problems that are often experienced by PT. PLN Engineering such as late arrivals and lack of quality equipment and stationery from suppliers, therefore it needs to be re-ordered or returned to suppliers, so that time is wasted. Storage of data on procurement of equipment and stationery that are still conventional so that it is not effective and efficient in terms of time, cost and energy, let alone supplier selection which is still subjective. The purpose of this study makes it easier for competent parties to make decisions at PT. PLN Engineering in selecting the best supplier to be consistent in maintaining the determined criteria so as to minimize the risk and not disappoint the company. Incorrect supplier selection affects the quality and costs incurred in buying equipment and stationery from suppliers, how to overcome them requires a decision support system (SPK) that is able to accurately select the most suitable supplier. The method of Simple Additive Weighting (SAW) combined with fuzification is the right method for evaluating the best suppliers. The most important criteria are Price of Goods, Quality of Goods, Delivery Time, Location Distance, Goods Packaging, Accuracy of Goods, Flexibility, Track Record. The conclusion of the test results is the SAW method is able to show that the ranking of the best suppliers with the highest value of 0.89 is UD. Bintang Mulia.
\end{abstract}

Keywords: Supplier, Equipment and ATK, SAW, fuzzification

Abstrak

Perlengkapan dan Alat Tulis Kantor (ATK) merupakan perlengkapan yang sering dipergunakan di kantor, perusahaan dan organisasi, diantaranya filling kabinet, perforator, kalkulator, penjepit kertas, stapler, numerator, guide, flashdisk, pelubang kertas, pulpen dan kertas, paper shredder, komputer, printer, mesin faksimili, mesin fotocopy, map arsip dan kas register, serta furnitur kantor. Supplier merupakan bagian dari rantai pemasok yang berpengaruh pada berkembangnya suatu perusahaan. Masalah yang sering dialami PT. PLN Enjiniring seperti keterlambatan kedatangan dan kurangnya kualitas perlengkapan dan ATK dari supplier, oleh karena itu perlu dipesan ulang atau dikembalikan kepada supplier, sehingga terjadi pemborosan waktu. Penyimpanan data pengadaan perlengkapan dan ATK yang masih secara konvensional sehingga tidak efektif dan efesien dari segi waktu, biaya dan tenaga, apalagi pemilihan supplier yang masih secara subjektif. Tujuan penelitian ini memudahkan pihak yang berkompeten untuk pengambilan keputusan pada PT. PLN Enjiniring dalam pemilihan supplier terlayak agar konsisten dalam mempertahankan kriteria yang telah ditentukan sehingga mampu memperkecil resiko dan tidak mengecewakan perusahaan. Pemilihan supplier yang salah berdampak pada kualitas dan biaya yang dikeluarkan untuk membeli perlengkapan dan ATK dari supplier, cara mengatasinya dibutuhkan sebuah sistem pendukung keputusan (SPK) yang mampu memilih supplier terlayak secara akurat. Metode Simple Additive Weighting (SAW) dikombinasikan dengan fuzifikasi merupakan metode yang tepat untuk melakukan penilaian supplier terlayak. 
Kriteria terpenting adalah Harga Barang, Kualitas Barang, Waktu Pengiriman, Jarak Lokasi, Pengemasan Barang, Ketepatan Jumlah Barang, Fleksibilitas, Track Record. Kesimpulan hasil pengujian yaitu metode SAW mampu memperlihatkan ranking supplier terlayak dengan nilai tertinggi 0.89 adalah UD. Bintang Mulia.

Kata kunci: Supplier, Perlengkapan dan ATK, SAW, fuzzifikasi

\section{PENDAHULUAN}

Faktor utama sebuah perusahaan dapat memenuhi kebutuhan konsumen salah satunya dengan adanya supplier. Peran supplier sangat penting dalam suatu perusahaan, agar aktivitas perusahaan dapat berjalan dengan lancar maka supplier harus konsisten menjaga ketersediaan barang, namun masalah yang terjadi adalah dengan mempertimbangkan kriteria yang diinginkan sulit menentukan supplier terlayak dari banyak pilihan yang ada. Resiko dapat dihindari bila dilakukan pemilihan supplier dengan tepat dan akurat. Dalam hal memilih dan mencari supplier, harus ditentukan oleh orang-orang yang kompeten dalam pengambilan keputusan tersebut. Kemudian dalam[1] dijelaskan bahwa penelitian dilakukan di perusahaan otomotif yang berada di Iran sudah menghabiskan energi, waktu dan biaya yang besar untuk memilih supplier sesuai dengan kriteria yang diinginkan. Selanjutnya peneliti[2] membahas mengenai perlengkapan dan ATK Kantor adalah perlengkapan yang digunakan sehari-hari di kantor, perusahaan dan organisasi, terdiri dari penjepit kertas, staples, pelubang kertas, pulpen dan kertas, komputer, printer, mesin faksimili, mesin foto kopi dan kas register, bilik, lemari arsip dan meja.

PT. Prima Layanan Nasional Enjiniring (PT. PLN Enjiniring) adalah anak perusahaan PT. PLN (Persero), yang bergerak di bidang Konsultan Enjiniring, Rekayasa Enjiniring dan Supervisi Konstruksi, yang menyediakan teknik dan layanan untuk sektor listrik dan non listrik. Selama ini pemilihan supplier perlengkapan dan ATK di PT. PLN Enjiniring berdasarkan referensi dari para pegawai dan sales yang datang ke kantor. Kualitas barang dan service dari supplier tersebut awalnya cukup baik namun seiring waktu mulai mengecewakan, sehingga para pegawai yang menggunakan perlengkapan dan ATK kantor sering mengeluh karena menghambat kinerja mereka dalam melaksanakan tugasnya. Supplier sering terlambat dalam melakukan pengiriman perlengkapan dan ATK saat dibutuhkan, oleh sebab itu sangat diperlukan Sistem Pendukung Keputusan pemilihan supplier terlayak dengan memperhitungkan berbagai kriteria menggunakan metode Simple Additive Weighting (SAW) atau metode penjumlahan terbobot. Proses pemilihan supplier menggunakan berbagai kriteria dapat diselesaikan dengan sistem komputer yang mampu berinteraksi dengan bagian pengambil keputusan.

Penerapan metode Simple Additive Weighting (SAW) untuk memilih penari berkualitas berdasarkan kriteria yang telah ditentukan kemampuan menari fleksibilitas fisik, terampil, gesit, percaya diri, memiliki kemampuan, mengisi formulir, dan sertifikat prestasi. Tingkat validitasnya cenderung naik karena semakin banyak sampel yang digunakan. Hasil akhir dari penelitian 
adalah sebuah alternatif yang memiliki nilai terlayak dari alternatif yang ada, yaitu penari yang memiliki nilai tertinggi dengan skor 100 diperoleh dari $\mathrm{V}_{2}$ [3]. Dalam penelitiannya membangun aplikasi pengelompokan kemiskinan di wilayah Pringsewu dalam bentuk indeks kemiskinan, data yang ada dapat menjadi referensi untuk meningkatkan potensi daerah dengan mengurangi tingkat kemiskinan setiap tahun dengan metode SAW, namun dalam proses pengerjaannya tidak dilakukan proses fuzzifikasi[4]. Menggunakan metode SAW dikombinasikan dengan metode WP untuk mendukung pengambilan keputusan dalam proses menyeleksi karyawan baru dengan menggunakan nilai kriteria wawancara, uji lapangan, tes psikologi, dan pemeriksaan kesehatan[5].

Melihat pentingnya pemilihan supplier dan beberapa permasalahan yang dihadapi oleh PT. PLN Enjiniring, maka kebijakan tentang pemilihan supplier ini harus menjadi perhatian khusus demi kelangsungan bisnis perusahaan. Oleh karena itu, perlu adanya penilaian terstruktur dalam proses pemilihan supplier yang dilakukan oleh perusahaan. Metode Simple Additive Weighting (SAW) menjadi suatu metode yang dapat dimanfaatkan untuk menilai supplier. Penelitian ini bertujuan untuk melakukan penilaian terhadap kinerja dan penyeleksian supplier berdasarkan kriteria yang sudah ditetapkan, sehingga PT. PLN Enjiniring dapat memilih dan memperoleh supplier yang tepat dan terlayak secara objektif.

\section{METODOLOGI PENELITIAN}

\subsection{Logika Fuzzi}

Himpunan fuzzy merupakan suatu kelompok yang digunakan sebagai gambaran kondisi yang tertentu dalam variabel fuzzy. Representasi himpunan fuzzy terdiri atas 2 atribut yaitu linguistik yang merupakan penamaan kelompok menggunakan bahasa alami seperti muda, paruh baya, tua, dan sangat tua. Atribut kedua direpresentasikan secara numerik ataupun angka yang biasanya menunjukkan ukuran tertentu dari suatu variabel seperti 32, 40, 50, 60[6][7].

\subsection{Simple Additive Weighting (SAW)}

Metode Simple Additive Weighting (SAW) sering juga dikenal istilah metode penjumlahan terbobot [8]. Formula yang digunakan untuk melakukan normalisasi adalah sebagai berikut:

$\mathrm{R}_{\mathrm{ij}}=\left\{\begin{array}{l}\frac{x_{i j}}{\operatorname{Max} X_{i j}} \text { jika j adalah atribut keuntungan (benefit) } \\ \frac{\operatorname{Min}_{i j}}{X_{i j}} \text { jika } j \text { adalah atribut keluntungan (cost) } X_{i j}\end{array}\right\}$

Keterangan:

$\mathrm{Rij}=$ Rating kinerja ternormalisasi dari alternatif $\mathrm{Ai}$ pada atribut $\mathrm{Cj}$ $: i=1,2, \ldots, m$ dan $j=1,2, \ldots, n$

Max $\mathrm{X}_{\mathrm{ij}}=$ Nilai terbesar dari setiap kriteria $\mathrm{i}$ 
Min $\mathrm{X}_{\mathrm{ij}}=$ Nilai terkecil dari setiap kriteria $\mathrm{i}$

$\mathrm{X}_{\mathrm{ij}} \quad=$ Nilai atribut yang dimiliki dari setiap kriteria

Benefit= Jika nilai terbesar adalah terlayak

Cost = Jika nilai terkecil adalah terlayak

Berikut ini merupakan langkah-langkah penyelesaian menggunakan metode SAW[10].

1. Memberikan nilai setiap alternatif (cara menghitung nilai rating kerja ternormalisasi (rij) dari alternatif Ai pada setiap criteria (Cj) yang sudah ditentukan, dimana nilai $i=1,2, \ldots . m$ dan $j=1,2, \ldots . n$.

2. Memberikan nilai bobot (W) yang juga didapat berdasarkan nilai crisp/tegas.

3. Melakukan normalisasi matriks dengan cara menghitung nilai rating kinerja ternormalisasi (rij) dari alternatif $\mathrm{A} i$ pada atribut $\mathrm{Cj}$ berdasarkan persamaan yang disesuaikan dengan jenis atribut (atribut keuntungan / benefit = MAKSIMUM atau atribut biaya $/$ cost = MINIMUM). Apabila berupa atribut keuntungan maka nilai crisp (Xij) dari setiap kolom atribut dibagi dengan nilai crisp Max (MAX Xij) dari tiap kolom, sedangkan untuk atribut biaya, nilai crisp MIN (MIN Xij) dari setiap kolom atribut dibagi dengan nilai crisp (Xij) setiap kolom.

4. Melakukan proses perangkingan alternatif (Vi) dengan cara mengalikan nilai bobot (Wi) dengan nilai rating kinerja ternormalisasi (rij).

Berikut ini adalah alur dari sistem yang diusulkan dalam penelitian ini, yang ditunjukkan pada Gambar 1.

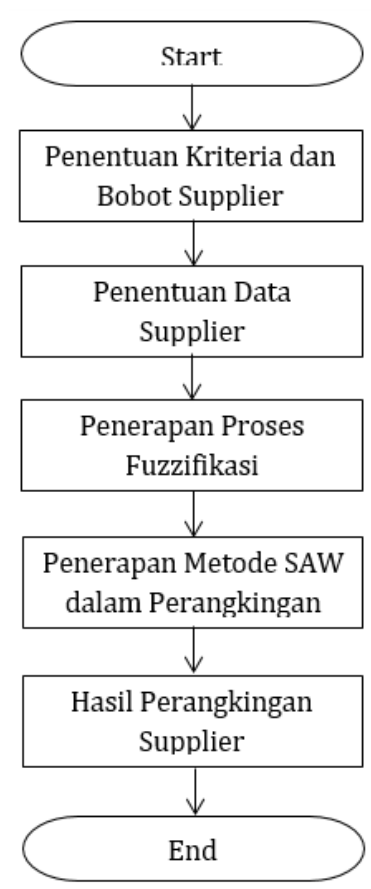

Gambar 1. Alur sistem yang diusulkan 


\section{HASIL DAN PEMBAHASAN}

\subsection{Pengumpulan Data}

Data yang diperlukan untuk melakukan analisa pemilihan supplier terlayak adalah hasil penilaian yang diberikan oleh para staff professional yang berpengalaman pada PT. PLN Enjiniring.

\subsection{Analisis dengan Metode SAW}

Dalam penyelesaian pemilihan supplier dengan menggunakan metode Simple Additive Weighting di perlukan kriteria-kriteria dan bobot untuk melakukan perhitungan sehingga akan didapat alternatif terlayak.

\section{a. Kriteria dan Bobot}

Dalam proses SAW memerlukan kriteria yang akan dijadikan bahan pertimbangan pada proses perankingan kriteria yang menjadi bahan pertimbangan dapat dilihat pada tabel 1 dibawah ini.

Tabel 1. Kriteria Dan Bobot

\begin{tabular}{|l|l|l|l|}
\hline Kode & Ketentuan Kriteria & Status & Bobot \\
\hline C1 & Harga Barang (HB) & Cost & 0.25 \\
\hline C2 & Kualitas Barang (KB) & Benafit & 0.20 \\
\hline C3 & Waktu Pengiriman (WP) & Benafit & 0.15 \\
\hline C4 & Jarak Lokasi (JK) & Benafit & 0.10 \\
\hline C5 & Pengemasan Barang (PB) & Benafit & 0.10 \\
\hline C6 & Ketepatan Jumlah Barang (KJB) & Benafit & 0.10 \\
\hline C7 & Fleksibilitas (F) & Benafit & 0.05 \\
\hline C8 & Track Record (TR) & Benafit & 0.05 \\
\hline
\end{tabular}

Dari kriteria di atas, maka dibuat satu tingkat kepentingan kriteria berdasarkan nilai bobot yang telah ditentukan ke dalam tabel 2 .

Tabel 2. Nilai Bobot Fuzzy

\begin{tabular}{|l|l|l|}
\hline Range Penilaian Supplier & Keterangan & Nilai \\
\hline $86-100$ & Sangat Baik (SB) & 1 \\
\hline $76-85$ & Baik (B) & 0.8 \\
\hline $66-75$ & Cukup (C) & 0.6 \\
\hline $56-65$ & Kurang (K) & 0.2 \\
\hline $0-55$ & Sangat Kurang (SK) & 0 \\
\hline
\end{tabular}

Bobot diperoleh dari bobot fuzzi. Selanjutnya dinyatakan dalam bentuk gambar yaitu pada gambar 2. Bilangan fuzzy untuk bobotnya. 


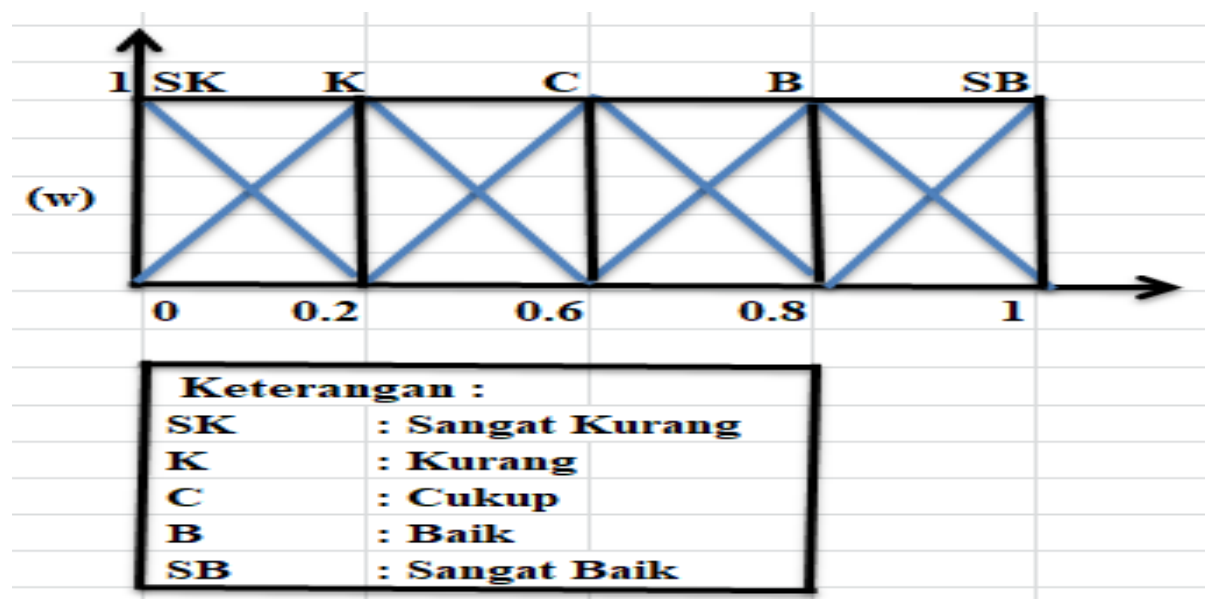

Gambar 2. Bilangan Fuzzy untuk Bobot

Dari gambar 3. dapat dilihat bahwa fuzzyfikasi yaitu suatu proses untuk mengubah suatu masukan dari bentuk tegas (crisp) menjadi fuzzy (variabel linguistik) yang biasanya disajikan dalam bentuk himpunan-himpunan fuzzy dengan suatu fungsi kenggotaannya masing-masing[11]. Misal jika ada nilai dengan kategori Sangat Kurang sampai dengan Kurang maka pada fuzzi akan bernilai 0-0.2.

\section{b. Parameter yang digunakan dalam sistem dan perhitungan.}

1) Kriteria Nilai Harga Barang.

Kriteria harga barang merupakan persyaratan yang dibutuhkan untuk pengambilan keputusan, berdasarkan sesuai harga barang dari masingmasing supplier. Berikut interval nilai harga barang yang telah dikonversikan dengan bilangan fuzzy dibawah ini.

Tabel 3. Nilai Harga Barang

\begin{tabular}{|l|l|}
\hline Keterangan & Nilai \\
\hline Sangat Baik (SB) & 1 \\
\hline Baik (B) & 0.8 \\
\hline Cukup (C) & 0.6 \\
\hline Kurang (K) & 0.2 \\
\hline Sangat Kurang (SK) & 0 \\
\hline
\end{tabular}

2) Kriteria Nilai Kualitas Barang.

Kriteria kualitas barang merupakan persyaratan yang dibutuhkan untuk pengambilan keputusan, berdasarkan kualitas barang yang diperoleh berdasarkan barang yang di terima dari supplier. Berikut interval nilai kualitas barang yang telah dikonversikan dengan bilangan fuzzy dibawah ini.

Tabel 4. Nilai Kualitas Barang

\begin{tabular}{|l|l|}
\hline Keterangan & Nilai \\
\hline Sangat Baik (SB) & 1 \\
\hline Baik (B) & 0.8 \\
\hline
\end{tabular}




\begin{tabular}{|l|l|}
\hline Keterangan & Nilai \\
\hline Cukup (C) & 0.6 \\
\hline Kurang (K) & 0.2 \\
\hline Sangat Kurang (SK) & 0 \\
\hline
\end{tabular}

3) Kriteria Nilai Waktu Pengiriman.

Kriteria waktu pengiriman merupakan persyaratan yang dibutuhkan untuk pengambilan keputusan, berdasarkan ketepatan waktu dalam pengiriman barang dari supplier. Berikut interval nilai waktu pengiriman yang telah dikonversikan dengan bilangan fuzzy dibawah ini.

Tabel 5. Nilai Waktu Pengiriman

\begin{tabular}{|l|l|}
\hline Keterangan & Nilai \\
\hline Sangat Baik (SB) & 1 \\
\hline Baik (B) & 0.8 \\
\hline Cukup (C) & 0.6 \\
\hline Kurang (K) & 0.2 \\
\hline Sangat Kurang (SK) & 0 \\
\hline
\end{tabular}

4) Kriteria Jarak Lokasi.

Kriteria jarak lokasi merupakan persyaratan yang dibutuhkan untuk pengambil keputusan, berdasarkan bagaimana jarak tempuh pengantaran perlengkapan dan ATK. Berikut interval nilai jarak lokasi yang telah dikonversikan dengan bilangan fuzzy dibawah ini.

Tabel 6.Nilai Jarak Lokasi

\begin{tabular}{|l|l|}
\hline Keterangan & Nilai \\
\hline Sangat Baik (SB) & 1 \\
\hline Baik (B) & 0.8 \\
\hline Cukup (C) & 0.6 \\
\hline Kurang (K) & 0.2 \\
\hline Sangat Kurang (SK) & 0 \\
\hline
\end{tabular}

5) Kriteria Nilai Pengemasan Barang.

Kriteria pengemasan barang merupakan persyaratan yang dibutuhkan untuk pengambilan keputusan, berdasarkan pengemasan barang yang dilakukan oleh supplier. Berikut interval nilai pengemasan barang yang telah dikonversikan dengan bilangan fuzzy dibawah ini.

Tabel 7. Nilai Pengemasan Barang

\begin{tabular}{|l|l|}
\hline Keterangan & Nilai \\
\hline Sangat Baik (SB) & 1 \\
\hline Baik (B) & 0.8 \\
\hline Cukup (C) & 0.6 \\
\hline Kurang (K) & 0.2 \\
\hline
\end{tabular}




\begin{tabular}{|l|l|}
\hline Keterangan & Nilai \\
\hline Sangat Kurang (SK) & 0 \\
\hline
\end{tabular}

6) Kriteria Nilai Ketepatan Jumlah Barang.

Kriteria ketepatan jumlah barang merupakan persyaratan yang dibutuhkan untuk pengambilan keputusan. Berikut interval nilai ketepatan jumlah barang yang telah dikonversikan dengan bilangan fuzzy dibawah ini.

Tabel 8. Nilai Ketepatan Jumlah Barang

\begin{tabular}{|l|l|}
\hline Keterangan & Nilai \\
\hline Sangat Baik (SB) & 1 \\
\hline Baik (B) & 0.8 \\
\hline Cukup (C) & 0.6 \\
\hline Kurang (K) & 0.2 \\
\hline Sangat Kurang (SK) & 0 \\
\hline
\end{tabular}

7) Kriteria Nilai Fleksibilitas

Kriteria fleksibilitas merupakan persyaratan yang dibutuhkan untuk pengambilan keputusan, berdasarkan fleksibilitas yang diberikan oleh supplier. Berikut interval nilai fleksibilitas yang telah dikonversikan dengan bilangan fuzzy dibawah ini.

Tabel 9. Nilai Fleksibilitas

\begin{tabular}{|l|l|}
\hline Keterangan & Nilai \\
\hline Sangat Baik (SB) & 1 \\
\hline Baik (B) & 0.8 \\
\hline Cukup (C) & 0.6 \\
\hline Kurang (K) & 0.2 \\
\hline Sangat Kurang (SK) & 0 \\
& \\
\hline
\end{tabular}

8) Kriteria Nilai Track Record

Kriteria track record merupakan persyaratan yang dibutuhkan untuk pengambilan keputusan, berdasarkan track record yang diberikan oleh supplier. Berikut interval nilai track record yang telah dikonversikan dengan bilangan fuzzy dibawah ini.

Tabel 10. Nilai Track Record

\begin{tabular}{|l|l|}
\hline Keterangan & Nilai \\
\hline Sangat Baik (SB) & 1 \\
\hline Baik (B) & 0.8 \\
\hline Cukup (C) & 0.6 \\
\hline Kurang (K) & 0.2 \\
\hline Sangat Kurang (SK) & 0 \\
\hline
\end{tabular}


Dari kriteria di atas maka di dapat data penilaian supplier menggunakan nilai numerik pada tahap awal yang ditabulasikan pada tabel 11 dibawah ini.

Tabel 11. Data Penilaian Supplier

\begin{tabular}{|l|l|l|l|l|l|l|l|l|}
\hline \multirow{2}{*}{ Alternatif } & \multicolumn{7}{|c|}{ Kriteria } \\
\cline { 2 - 10 } & C1 & C2 & C3 & C4 & C5 & C6 & C7 & C8 \\
\hline UD. Jaya Diesel & 80 & 87 & 90 & 85 & 78 & 75 & 70 & 76 \\
\hline UD. Makmur Jaya & 70 & 75 & 80 & 78 & 65 & 70 & 85 & 75 \\
\hline UD. Sinar Bahari & 75 & 80 & 70 & 72 & 77 & 90 & 75 & 85 \\
\hline UD. Berkah & 78 & 90 & 80 & 78 & 75 & 70 & 80 & 78 \\
\hline UD. Pancur Jaya & 76 & 70 & 80 & 78 & 73 & 78 & 70 & 75 \\
\hline UD. Naga Mas & 85 & 75 & 76 & 80 & 90 & 83 & 78 & 70 \\
\hline UD. Bintang Mulia & 72 & 76 & 85 & 82 & 85 & 78 & 80 & 77 \\
\hline
\end{tabular}

Tabel $11 \mathrm{di}$ atas, data penilaian supplier menggunakan nilai numerik selanjutnya pada tabel 12 dibawah ini, data penilaian supplier tersebut dikonversi menjadi nilai linguistik.

Tabel 12. Data Penilaian Supplier

\begin{tabular}{|l|l|l|l|l|l|l|l|l|}
\hline \multirow{2}{*}{ Alternatif } & \multicolumn{7}{|c|}{ Kriteria } \\
\cline { 2 - 10 } & C1 & C2 & C3 & C4 & C5 & C6 & C7 & C8 \\
\hline UD. Jaya Diesel & B & SB & SB & B & B & C & C & B \\
\hline UD. Makmur Jaya & C & C & B & B & K & C & B & C \\
\hline UD. Sinar Bahari & C & B & C & C & B & SB & C & B \\
\hline UD. Berkah & B & SB & B & B & C & C & B & B \\
\hline UD. Pancur Jaya & B & C & B & B & C & B & C & C \\
\hline UD. Naga Mas & B & C & B & B & SB & B & B & C \\
\hline UD. Bintang Mulia & C & B & B & B & B & B & B & B \\
\hline
\end{tabular}

Data-data dalam tabel di atas digunakan untuk memodelkan sistem dan diproses dengan menggunakan metode SAW dengan proses fuzzifikasi. Manfaat dari proses fuzzifikasi adalah agar menghasilkan nilai lebih valid dan akurat karena fuzzifikasi dapat menentukan nilai yang tadinya numerik/nilai pasti dalam bentuk angka dikonversi menjadi bentuk linguistik ataupun sebaliknya.

Pada Tabel 13, adalah data rating kecocokan dari setiap alternatif terhadap kriteria, data diambil dari staff profesional PT. PLN Injiniring yang memasukkan inputan ke aplikasi. Proses perhitungan di awali dengan membuat rating kecocokan penilaian supplier dan diberikan nilai sesuai bobot dengan fuzzifikasi. 
Tabel 13. Rating Kecocokan Setiap Alternatif

\begin{tabular}{|l|l|l|l|l|l|l|l|l|}
\hline \multirow{2}{*}{ Alternatif } & \multicolumn{7}{|c|}{ Kriteria } \\
\cline { 2 - 11 } & $\mathrm{C} 1$ & $\mathrm{C} 2$ & $\mathrm{C} 3$ & $\mathrm{C} 4$ & $\mathrm{C} 5$ & $\mathrm{C} 6$ & $\mathrm{C7}$ & C8 \\
\hline UD. Jaya Diesel & 0.8 & 1 & 1 & 0.8 & 0.8 & 0.6 & 0.6 & 0.8 \\
\hline UD. Makmur Jaya & 0.6 & 0.6 & 0.8 & 0.8 & 0.2 & 0.6 & 0.8 & 0.6 \\
\hline UD. Sinar Bahari & 0.6 & 0.8 & 0.6 & 0.6 & 0.8 & 1 & 0.6 & 0.8 \\
\hline UD. Berkah & 0.8 & 1 & 0,8 & 0.8 & 0.6 & 0.6 & 0.8 & 0.8 \\
\hline UD. Pancur Jaya & 0.8 & 0.6 & 0,8 & 0.8 & 0.6 & 0.8 & 0.6 & 0.6 \\
\hline UD. Naga Mas & 0.8 & 0.6 & 0.8 & 0.8 & 1 & 0.8 & 0.8 & 0.6 \\
\hline UD. Bintang Mulia & 0.6 & 0.8 & 0.8 & 0.8 & 0.8 & 0.8 & 0.8 & 0.8 \\
\hline
\end{tabular}

Langkah selanjutnya adalah membuat matriks keputusan X. Matriks ini dibuat dari tabel rating kecocokan (tabel 13) sebagai berikut ini:

$$
\mathrm{X}=\left|\begin{array}{llllllll}
0.8 & 1 & 1 & 0.8 & 0.8 & 0.6 & 0.6 & 0.8 \\
0.6 & 0.6 & 0.8 & 0.8 & 0.2 & 0.6 & 0.8 & 0.6 \\
0.6 & 0.8 & 0.6 & 0.6 & 0.8 & 1 & 0.6 & 0.8 \\
0.8 & 1 & 0.8 & 0.8 & 0.6 & 0.6 & 0.8 & 0.8 \\
0.8 & 0.6 & 0.8 & 0.8 & 0.6 & 0.8 & 0.6 & 0.6 \\
0.8 & 0.6 & 0.8 & 0.8 & 1 & 0.8 & 0.8 & 0.6 \\
0.6 & 0.8 & 0.8 & 0.8 & 0.8 & 0.8 & 0.8 & 0.8
\end{array}\right|
$$

Langkah selanjutnya melakukan Normalisasi matriks X untuk menghitung nilai masing-masing kriteria berdasarkan kriteria diasumsikan sebagai kriteria keuntungan (benefit) atau biaya (cost). Pada tahap ini harus dilakukan normalisasi yang awalnya dari matriks $\mathrm{X}$ menjadi matriks $\mathrm{r}, \mathrm{r}$ merupakan simbol dari variabel sebuah matriks, nilai sebuah matriks $r$ terdiri dari kumpulan nilai ternormalisasi yang disimbolkan dalam variabel $r$. Nilai $r$ diperoleh dari rumus (1). Adapun proses normalisasi matriks $\mathrm{X}$ menjadi $r$ adalah sebagai berikut :

1. Normalisasi terhadap Harga Barang (C1) yang berpengaruh kepada Cost :

$$
\begin{aligned}
& r_{11}=\frac{\min (0.8,0.6,0.6,0.8,0.8,0.8,0.6)}{0.8}=0 . \overline{8}=0.75 \\
& r_{21}=\frac{\min (0.8,0.6,0.6,0.8,0.8,0.8,0.6)}{0.6}=\frac{0.6}{0.6}=1 \\
& r_{31}=\frac{\min (0.8,0.6,0.6,0.8,0.8,0.8,0.6)}{0.6}=\frac{0.6}{0.6}=1 \\
& r_{41}=\frac{\min (0.8,0.6,0.6,0.8,0.8,0.8,0.6)}{0.8}=\frac{0.6}{0.8}=0.75 \\
& r_{51}=\frac{\min (0.8,0.6,0.6,0.8,0.8,0.8,0.6)}{0.8}=0 . \overline{0.6}=0.75 \\
& r_{61}=\frac{\min (0.8,0.6,0.6,0.8,0.8,0.8,0.6)}{0.8}=\frac{0.6}{0.8}=0.75 \\
& r_{71}=\frac{\min (0.8,0.6,0.6,0.8,0.8,0.8,0.6)}{0.6}=0 . \overline{0.6}=1 \\
& 0.6
\end{aligned}
$$


Pada point 1 semua komponen nilai C1 sangat berdampak terhadap proses pembiayaan di PT. PLN Enjiniring.

2. Normalisasi terhadap Kualitas Barang (C2) yang berpengaruh kepada Benefit :

\begin{tabular}{|c|c|c|}
\hline $2=$ & $\frac{1}{\max (1,0.6,0.8,1,0.6}$ & $1 \frac{=1}{1}$ \\
\hline 2 & 0.6 & $0.6 \underline{=0}$ \\
\hline $2=$ & $\frac{0.8}{8,1,0.6}$ & $0.8 \frac{=0}{1}$. \\
\hline & 1 & $1=1$ \\
\hline & $\frac{0.6}{8,1,0.6}$ & $0.6 \underline{1}=0.6$ \\
\hline & 0.6 & $0.6 \frac{=0}{1}$ \\
\hline & 0.8 & $0.8=0$. \\
\hline
\end{tabular}

Pada point 2 nilai C2 memberikan pengaruh keuntungan kepada PT. PLN Enjiniring dalam menilai supplier terlayak.

3. Normalisasi terhadap Waktu Pengiriman (C3) yang berpengaruh kepada Benefit:

$$
\begin{aligned}
& \mathrm{r}_{13}=\frac{1}{\max (1,0.8,0.6,0.8,0.8,0.8,0.8)} 1=1 \\
& \mathrm{r}_{23}=\frac{0.8}{\max (1,0.8,0.6,0.8,0.8,0.8,0.8)}=0.8=0.8 \\
& \mathrm{r}_{33}=\frac{0.6}{\max (1,0.8,0.6,0.8,0.8,0.8,0.8)}=0.6=0.6 \\
& \mathrm{r}_{43}=\frac{0.8=0.8=0.8}{\max (1,0.8,0.6,0.8,0.8,0.8,0.8)} 1 \\
& \mathrm{r}_{53}=\frac{0.8}{\max (1,0.8,0.6,0.8,0.8,0.8,0.8)}=0.8=0.8 \\
& \mathrm{r}_{63}=\frac{0.8}{\max (1,0.8,0.6,0.8,0.8,0.8,0.8)}=0.8=0.8 \\
& \mathrm{r}_{73}=\frac{0.8}{\max (1,0.8,0.6,0.8,0.8,0.8,0.8)}=0.8=0.8
\end{aligned}
$$

Pada point 3 nilai C3 memberikan pengaruh keuntungan kepada PT. PLN Enjiniring dalam menilai supplier terlayak.

4. Normalisasi terhadap Jarak Lokasi (C4) yang berpengaruh kepada Benefit : $\mathrm{r}_{14}=\frac{0.8}{\max (0.8,0.8,0.6,0.8,0.8,0.8,0.8)}=\frac{0.8}{0.8}=1$ 


$$
\begin{aligned}
& \mathrm{r}_{24}=\frac{0.8}{\max (0.8,0.8,0.6,0.8,0.8,0.8,0.8)}=\frac{0.8}{0.8}=1 \\
& \mathrm{r}_{34}=\frac{0.6}{\max (0.8,0.8,0.6,0.8,0.8,0.8,0.8)}=\frac{0.6}{0.8}=0,75 \\
& r_{44} \frac{0.8}{\max (0.8,0.8,0.6,0.8,0.8,0.8,0.8)}=\frac{0.8}{0.8}=1 \\
& \mathrm{r}_{54}=\frac{0.8}{\max (0.8,0.8,0.6,0.8,0.8,0.8,0.8)} \quad=\frac{0.8}{0.8}=1 \\
& \mathrm{r}_{64}=\frac{0.8}{\max (0.8,0.8,0.6,0.8,0.8,0.8,0.8)}=\frac{0.8}{0.8}=1 \\
& \mathrm{r}_{74}=\frac{0.8}{\max (0.8,0.8,0.6,0.8,0.8,0.8,0.8)}=\frac{0.8}{0.8}=1
\end{aligned}
$$

Pada point 4 nilai C4 memberikan pengaruh keuntungan kepada PT. PLN Enjiniring dalam menilai supplier terlayak.

5. Normalisasi terhadap Pengemasan Barang (C5) yang berpengaruh kepada Benefit :

$$
\begin{aligned}
& r_{15}=\frac{0.8}{\max (0.8,0.2,0.8,0.6,0.6,1,0.8)}=\frac{0.8}{1}=0.8 \\
& r_{25}=\frac{0.2}{\max (0.8,0.2,0.8,0.6,0.6,1,0.8)}=\frac{0.2}{1}=\frac{0.8}{1}=0.8 \\
& r_{35}=\frac{0.8}{\max (0.8,0.2,0.8,0.6,0.6,1,0.8)}=\frac{0.6}{1}=0.6 \\
& r_{45}=\frac{0.6}{\max (0.8,0.2,0.8,0.6,0.6,1,0.8)}=\frac{0.6}{1}=0.6 \\
& r_{55}=\frac{0.6}{\max (0.8,0.2,0.8,0.6,0.6,1,0.8)}=\frac{1}{1}=1 \\
& r_{65}=\frac{1}{\max (0.8,0.2,0.8,0.6,0.6,1,0.8)}=\frac{0.8}{1}=0.8
\end{aligned}
$$

Pada point 5 nilai C5 memberikan pengaruh keuntungan kepada PT. PLN Enjiniring dalam menilai supplier terlayak.

6. Normalisasi terhadap Ketepatan Jumlah Barang (C6) yang berpengaruh kepada Benefit:

$$
\begin{aligned}
& \mathrm{r}_{16}=\frac{0.6}{\max (0.6,0.6,1,0.6,0.8,0.8,0.8)}=\frac{0.6}{1}=0.6 \\
& \mathrm{r}_{26}=\frac{0.6}{\max (0.6,0.6,1,0.6,0.8,0.8,0.8)}=\frac{0.6}{1}=0.6 \\
& \mathrm{r}_{36}=\frac{1}{\max (0.6,0.6,1,0.6,0.8,0.8,0.8)}=\frac{1}{1}=1 \\
& \mathrm{r}_{46}=\frac{0.6}{\max (0.6,0.6,1,0.6,0.8,0.8,0.8)}=\frac{0.6}{1}=0.6
\end{aligned}
$$




$$
\begin{array}{ll}
r_{56}=\frac{0.8}{\max (0.6,0.6,1,0.6,0.8,0.8,0.8)} & =\frac{0.8}{1}=0.8 \\
r_{66}=\frac{0.8}{\max (0.6,0.6,1,0.6,0.8,0.8,0.8)} & =\frac{0.8}{1}=0.8 \\
r_{76}=\frac{0.8}{\max (0.6,0.6,1,0.6,0.8,0.8,0.8)} & =\frac{0.8}{1}=0.8
\end{array}
$$

Pada point 6 nilai C6 memberikan pengaruh keuntungan kepada PT. PLN Enjiniring dalam menilai supplier terlayak.

7. Normalisasi terhadap Fleksibilitas (C7) yang berpengaruh kepada Benefit :

$$
\begin{array}{ll}
r_{17}=\frac{0.6}{\max (0.6,0.8,0.6,0.8,0.6,0.8,0.8)} & =\frac{0.6}{0.8}=0.75 \\
r_{27}=\frac{0.8}{\max (0.6,0.8,0.6,0.8,0.6,0.8,0.8)} & =\frac{0.8}{0.8}=1 \\
r_{37}=\frac{0.6}{\max (0.6,0.8,0.6,0.8,0.6,0.8,0.8)} & =\frac{0.6}{0.8}=0.75 \\
r_{47}=\frac{0.8}{\max (0.6,0.8,0.6,0.8,0.6,0.8,0.8)} & =\frac{0.8}{0.8}=1 \\
r_{57}=\frac{0.6}{\max (0.6,0.8,0.6,0.8,0.6,0.8,0.8)} & =\frac{0.6}{0.8}=0.75 \\
r_{67}=\frac{0.8}{\max (0.6,0.8,0.6,0.8,0.6,0.8,0.8)} & =\frac{0.8}{0.8}=1 \\
r_{77}=\frac{0.8}{\max (0.6,0.8,0.6,0.8,0.6,0.8,0.8)} & =\frac{0.8}{0.8}=1
\end{array}
$$

Pada point 7 nilai C7 memberikan pengaruh keuntungan kepada PT. PLN Enjiniring dalam menilai supplier terlayak.

8) Normalisasi terhadap Track Record (C8) yang berpengaruh kepada Benefit :

$$
\begin{array}{ll}
\mathrm{r}_{18}=\frac{0.8}{\max (0.8,0.6,0.8,0.8,0.6,0.6,0.8)} & =\frac{0.8}{0.8}=1 \\
\mathrm{r}_{28}=\frac{0.6}{\max (0.8,0.6,0.8,0.8,0.6,0.6,0.8)} & =\frac{0.6}{0.8}=0.75 \\
\mathrm{r}_{38}=\frac{0.8}{\max (0.8,0.6,0.8,0.8,0.6,0.6,0.8)} & =\frac{0.8}{0.8}=1 \\
\mathrm{r}_{48}=\frac{0.8}{\max (0.8,0.6,0.8,0.8,0.6,0.6,0.8)} & =\frac{0.8}{0.8}=1 \\
\mathrm{r}_{58}=\frac{0.6}{\max (0.8,0.6,0.8,0.8,0.6,0.6,0.8)} & =\frac{0.6}{0.8}=0.75 \\
\mathrm{r}_{68}=\frac{0.6}{\max (0.8,0.6,0.8,0.8,0.6,0.6,0.8)} & =\frac{0.6}{0.8}=0.75 \\
\mathrm{r}_{78}=\frac{0.8}{\max (0.8,0.6,0.8,0.8,0.6,0.6,0.8)} & =\underline{0.8}=1
\end{array}
$$


Pada point 8 nilai C8 memberikan pengaruh keuntungan kepada PT. PLN Enjiniring dalam menilai supplier terlayak.

Dari perhitungan point 1 sampai dengan 8 akan menghasilkan sebuah matriks ternormalisasi r sebagai berikut:

$$
\mathrm{r}=\left(\begin{array}{llllllll}
0.75 & 1 & 1 & 1 & 0.8 & 0.6 & 0.75 & 1 \\
1 & 0.6 & 0.8 & 1 & 0.2 & 0.6 & 1 & 0.75 \\
1 & 0.8 & 0.6 & 0.75 & 0.8 & 1 & 0.75 & 1 \\
0.75 & 1 & 0.8 & 1 & 0.6 & 0.6 & 1 & 1 \\
0.75 & 0.6 & 0.8 & 1 & 0.6 & 0.8 & 0.75 & 0.75 \\
0.75 & 0.6 & 0.8 & 1 & 1 & 0.8 & 1 & 0.75 \\
1 & 0.8 & 0.8 & 1 & 0.8 & 0.8 & 1 & 1
\end{array}\right)
$$

c. Proses Perangkingan

Tahap akhir dalam melakukan penilaian supplier terlayak adalah tahap perangkingan. Dari tahap ini akan diperolah supplier yang menduduki posisi rangking tertinggi sampai terendah. Rangking supplier nantinya akan dapat memberikan solusi bagi pimpinan dalam mengambil suatu kebijakan.

Dari rumus diatas diperoleh nilai supplier terlayak setiap supplier sebagai berikut :

$$
\begin{aligned}
\mathrm{V}_{1}= & (0.25 \times 0.75)+(0.2 \times 1)+(0.15 \times 1)+(0.1 \times 1)+(0.1 \times 0.8)+(0.1 \times 0.6)+ \\
& (0.05 \times 0.75)+(0.05 \times 1)=\mathbf{0 . 8 6 5} \\
\mathrm{V}_{2}= & (0.25 \times 1)+(0.2 \times 0.6)+(0.15 \times 0.8)+(0.1 \times 1)+(0.1 \times 0.2)+(0.1 \times 0.6)+ \\
& (0.05 \times 1)+(0.05 \times 0.75)=\mathbf{0 . 7 5 7 5} \\
\mathrm{V}_{3}= & (0.25 \times 1)+(0.2 \times 0.8)+(0.15 \times 0.6)+(0.1 \times 0.75)+(0.1 \times 0.8)+(0.1 \times 1)+ \\
& (0.05 \times 0.75)+(0.05 \times 1)=\mathbf{0 . 8 4 2 5} \\
\mathrm{V}_{4}= & (0.25 \times 0.75)+(0.2 \times 1)+(0.15 \times 0.8)+(0.1 \times 1)+(0.1 \times 0.6)+(0.1 \times 0.6)+ \\
& (0.05 \times 1)+(0.05 \times 1)=\mathbf{0 . 8 2 7 5} \\
\mathrm{V}_{5}= & (0.25 \times 0.75)+(0.2 \times 0.6)+(0.15 \times 0.8)+(0.1 \times 1)+(0.1 \times 0.6)+(0.1 \times 0.8)+ \\
& (0.05 \times 0.75)+(0.05 \times 0.75)=\mathbf{0 . 7 4 2 5} \\
\mathrm{V}_{6}= & (0.25 \times 0.75)+(0.2 \times 0.6)+(0.15 \times 0.8)+(0.1 \times 1)+(0.1 \times 1)+(0.1 \times 0.8)+ \\
& (0.05 \times 1)+(0.05 \times 0.75)=\mathbf{0 . 7 9 5} \\
V_{7}= & (0.25 \times 1)+(0.2 \times 0.8)+(0.15 \times 0.8)+(0.1 \times 1)+(0.1 \times 0.8)+(0.1 \times 0.8)+ \\
& (0.05 \times 1)+(0.05 \times 1)=\mathbf{0 . 8 9}
\end{aligned}
$$

Dari perhitungan diatas didapatkan hasil perangkingan seperti dalam Tabel 14 berikut:

Tabel 14. Hasil Penilaian Supplier Terlayak

\begin{tabular}{|l|c|c|c|c|c|c|c|c|c|}
\hline \multirow{2}{*}{ Alternatif } & \multicolumn{8}{|c|}{ Kriteria } & \multirow{2}{*}{ Vi } \\
\cline { 2 - 10 } & $\mathrm{C} 1$ & $\mathrm{C} 2$ & $\mathrm{C} 3$ & $\mathrm{C} 4$ & $\mathrm{C} 5$ & $\mathrm{C} 6$ & $\mathrm{C} 7$ & $\mathrm{C} 8$ & \\
\hline UD. Jaya Diesel & 0,75 & 1 & 1 & 1 & 0.8 & 0.6 & 0.75 & 1 & $\mathbf{0 . 8 6 5}$ \\
\hline UD. Makmur Jaya & 1 & 0.6 & 0.8 & 1 & 0.2 & 0.6 & 1 & 0.75 & $\mathbf{0 . 7 5 7 5}$ \\
\hline UD. Sinar Bahari & 1 & 0.8 & 0.6 & 0.75 & 0.8 & 1 & 0.75 & 1 & $\mathbf{0 . 8 4 2 5}$ \\
\hline UD. Berkah & 0.75 & 1 & 0.8 & 1 & 0.6 & 0.6 & 1 & 1 & $\mathbf{0 . 8 2 7 5}$ \\
\hline UD. Pancur Jaya & 0.75 & 0.6 & 0.8 & 1 & 0.6 & 0.8 & 0.75 & 0.75 & $\mathbf{0 . 7 4 2 5}$ \\
\hline
\end{tabular}


http://tunasbangsa.ac.id/ejurnal/index.php/jsakti

\begin{tabular}{|c|c|c|c|c|c|c|c|c|c|}
\hline \multirow{2}{*}{ Alternatif } & \multicolumn{8}{|c|}{ Kriteria } & \multirow[t]{2}{*}{$\mathbf{V i}$} \\
\hline & C1 & $\mathrm{C} 2$ & C3 & $\mathrm{C} 4$ & $\mathrm{C} 5$ & C6 & $\mathrm{C} 7$ & C8 & \\
\hline UD. Naga Mas & 0.75 & 0.6 & 0.8 & 1 & 1 & 0.8 & 1 & 0.75 & 0.795 \\
\hline UD. Bintang Mulia & 1 & 0.8 & 0.8 & 1 & 0.8 & 0.8 & 1 & 1 & 0.89 \\
\hline
\end{tabular}

Dari perhitungan diatas didapatkan hasil perangkingan setelah di urutkan dari nilai tertinggi ke nilai terendah seperti dalam Tabel 15 berikut:

Tabel 15. Hasil Penilaian Supplier Terlayak

\begin{tabular}{|c|c|c|c|c|c|c|c|c|c|}
\hline Alternatif & \multicolumn{8}{|c|}{ Kriteria } & \\
\hline & $\mathrm{C} 1$ & $\mathrm{C} 2$ & $\mathrm{C} 3$ & $\mathrm{C} 4$ & $\mathrm{C} 5$ & $\mathrm{C} 6$ & $\mathrm{C} 7$ & $\mathrm{C} 8$ & Vi \\
\hline UD. Bintang Mulia & 1 & 0.8 & 0.8 & 1 & 0.8 & 0.8 & 1 & 1 & 0.89 \\
\hline UD. Jaya Diesel & 0,75 & 1 & 1 & 1 & 0.8 & 0.6 & 0.75 & 1 & 0.865 \\
\hline UD. Sinar Bahari & 1 & 0.8 & 0.6 & 0.75 & 0.8 & 1 & 0.75 & 1 & 0.8425 \\
\hline UD. Berkah & 0.75 & 1 & 0.8 & 1 & 0.6 & 0.6 & 1 & 1 & 0.8275 \\
\hline UD. Naga Mas & 0.75 & 0.6 & 0.8 & 1 & 1 & 0.8 & 1 & 0.75 & 0.795 \\
\hline UD. Makmur Jaya & 1 & 0.6 & 0.8 & 1 & 0.2 & 0.6 & 1 & 0.75 & 0.7575 \\
\hline UD. Pancur Jaya & 0.75 & 0.6 & 0.8 & 1 & 0.6 & 0.8 & 0.75 & 0.75 & 0.7425 \\
\hline
\end{tabular}

Kesimpulan yang bisa diambil dari hasil perhitungan Perfernsi tabel 15 diatas yaitu bahwa nilai tertinggi (0.89) ada pada V7. Dengan demikian alternatif A7 yaitu UD. Bintang Mulia adalah sebagai alternatif terlayak untuk menentukan supplier terlayak PT. PLN Enjiniring.

\section{SIMPULAN}

Dari analisa dan pembahasan yang telah dilakukan maka dapat ditarik beberapa kesimpulan antara lain sebagai berikut :

a) Sistem Pendukung Keputusan (SPK) pemilihan supplier dengan memperitungkan berbagai kriteria dalam menggunakan metode Simple Additive Wieghting (SAW) dikombinasi dengan logika fuzzy dapat memberikan hasil yang lebih baik dan tepat karena mengalami proses fuzzifikasi terlebih dahulu dan nilai bobot pada setiap kriteria mempengaruhi hasil dari sistem pemilihan supplier terlayak. Dengan adanya sistem tersebut akan sangat membantu dalam memberikan rekomendasi dan pertimbangan serta mengurangi tingkat kesalahan dalam pemilihan supplier terlayak di kantor, perusahaan atau organisasi melalui data perangkingan dari hasil yang telah diolah dan dapat diterapkan pada studi kasus yang lain.

b) Proses pemilihan supplier dengan berbagai kriteria dapat diselesaikan oleh sebuah sistem komputer yang mampu berinteraksi dengan pengambil keputusan.

\section{DAFTAR PUSTAKA}

[1] K. Shahroudi and H. Rouydel, "Using a multi-criteria decision making approach (ANP-TOPSIS) to evaluate suppliers in Iran's auto industry," Int. J. Appl. Oper. Res. J., vol. 2, no. 2, pp. 37-48, 2012. 
[2] Y. C. Sepdiantara and T. Haryanti, "Mandiri," Inf. Syst. Educ. Prof., vol. 1, no. 2, pp. 205-220, 2017.

[3] H. Adela, K. Azmi Jasmi, B. Basiron, M. Huda, and A. Maseleno, "Selection of dancer member using simple additive weighting," Int. J. Eng. Technol., vol. 7, no. 3, p. 1096, 2018.

[4] E. Yunaeti Anggraeni et al., "Poverty level grouping using SAW method," Int. J. Eng. Technol., vol. 7, no. 2.27, p. 218, 2018.

[5] A. Setyawan, F. Y. Arini, and I. Akhlis, "Comparative Analysis of Simple Additive Weighting Method and Weighted Product Method to New Employee Recruitment Decision Support System (DSS) at PT. Warta Media Nusantara," Sci. J. Informatics, vol. 4, no. 1, pp. 34-42, 2017.

[6] M. Munawar, M. Marzuki, and R. Radiah, "Pendeteksian Penyakit Diabetes di RSUD Zainoel Abidin Banda Aceh dengan Sistem Fuzzy Mamdani," J. Data Anal., vol. 1, no. 2, pp. 103-110, 2018.

[7] B. Subaeki, F. Gunawan, and A. R. Atmadja, "Penggunaan Metode Fuzzy Logic untuk Pemantauan Sentimen Brand pada Media Sosial", QUERY: Jurnal Sistem Informasi Vol.1, No.2, ISSN : 2579-5341, 2017.

[8] A. P. Windarto, "Implementasi Metode Topsis Dan Saw Dalam Memberikan Reward Pelanggan," Klik - Kumpul. J. Ilmu Komput., vol. 4, no. 1, p. 88, 2017.

[9] L. A. Ivanjelita, E. Utami and E. T. Luthfi, "Sistem Pendukung Keputusan Seleksi Penerimaan Calon Asisten Praktikum", Jurnal Ilmiah DASI, Vol. 16, No. 4, hlm 37 - 46 ISSN : 1411-3201, 2015

[10] F. Sonata, "Implementasi Metode Simple Additive Weighting (Saw) dengan Proses Fuzzifikasi dalam Penilaian Kinerja Dosen," J. Teknol. Inf. dan Komun., vol. 5, no. 2, pp. 71-80, 2016.

[11] A. L. Fernandes, "Penerapan Motion Detection Pada Sistem Kamera Keamanan Menggunakan Logika Fuzzy Berbasis Web Dengan Email Notification", Jurnal Teknik Ibnu Sina (JT-IBSI), Vol. 3, No. 1, ISSN : 25412647, 2018. 